\title{
Analysis And Evaluation of Pharmacist Power Needs With The WISN Method In The Pharmaceutical Installation of Haji Hospital Surabaya
}

\author{
Muhammad Subhan ${ }^{1}$, Ratna Wardani ${ }^{2}$, Dewi Ramdani ${ }^{3}$ \\ ${ }^{1}$ Strada Indonesia Institute of Science, ${ }^{2}$ Strada Indonesia Institute of Science, \\ ${ }^{3}$ Pharmaceutical Installation of Haji Hospital Surabaya
}

*Corresponding author. Email: muh.subhan1995@gmail.com

The success of hospitals in carrying out their functions is influenced by several factors, among which the most dominant is human resources, which is one of the important factors to be able to provide quality and comprehensive services in health services. The method of calculating needs based on workload (WISN) is an indicator that shows the need for personnel in health facilities based on workload, so that the allocation/relocation of personnel is easier and more rational. This research is a descriptive observational research with qualitative data analysis with purposive sampling method. The category of HR that will be calculated for its energy needs is Pharmacists at the Pharmacy Installation of Haji Hospital Surabaya and results in a calculation of the number of pharmacists needed by 24 people, compared to the current number of pharmacists at 20 pharmacists, the additional number of pharmacists is 4 people in the Home Pharmacy Installation. Surabaya Hajj Hospital. The current number of staff fulfillment from the calculation results only meets $83 \%$ of the ideal amount produced by the WISN method with the obstacles faced such as the large workload of clinical pharmacy services. To anticipate this, it is necessary to fulfill the need for pharmacists.

Keywords: Hospital, Human Resources, Pharmacy Installation, Pharmacist, WISN.

OPEN ACCESS ISSN 2528-4649 (online) ISSN 2338-4409 (print)

Reviewedby: Putu Anom Mahadwartha, Qristin Violinda

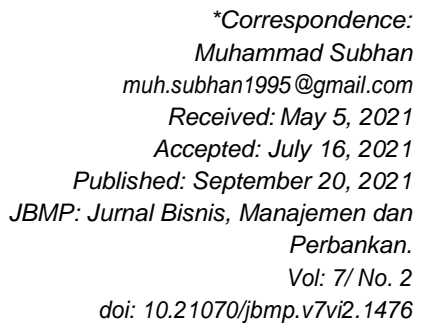

${ }^{*}$ Correspondence: Muhammad Subhan muh.subhan1995@gmail.com Received: May 5, 2021 Accepted: July 16, 2021 Published: September 20, 2021 JBMP: Jurnal Bisnis, Manajemen dan Perbankan. Vol: $7 /$ No. 2 doi: 10.21070/jbmp.v7vi2.1476 


\section{INTRODUCTION}

According to WHO (World Health Organization), the hospital is an integral part of a social and health organization with the function of providing comprehensive services, cure (curative) and disease prevention (preventive) to the community. The hospital is also a health service institution that plays a role in the implementation of health development. Permenkes number 3 of 2020 concerning Hospital Classification and Licensing also states that the Hospital Operational Permit or Operational Permit is a commercial or operational permit issued by the OSS Institution for and on behalf of the minister, governor, or regent / mayor after the hospital owner has obtained a permit. set up. Article 7 paragraph 2 states that the health services provided by the hospital at least consist of: a. medical services and medical support; b. nursing and midwifery services; and c. non-medical services (Permenkes, 2020).

In the previous Minister of Health Regulation (Permenkes or PMK) number 30 of 2019 concerning Hospital Classification and Licensing. Article 7 paragraph 2 states that the health services provided by public hospitals at least consist of: a. medical services; b. nursing and midwifery services; c. medical support services; and d. nonmedical support services. The pharmacy service itself in the previous PMK (2019) was included in other medical support services which included centralized sterilization services, blood services, medical records, and pharmacy in accordance with statutory provisions (Permenkes, 2019). The difference is that the pharmaceutical services from PMK 2019 are in the category of medical support services, while the 2020 PMK is in the non-medical service category.

In the Regulation of the Minister of Health (Permenkes or PMK) number 72 of 2016 concerning Standards for Pharmaceutical Services in Hospitals, article 3 paragraph 1 states that the Standards for Pharmaceutical Services in Hospitals are stated to include standards: a. management of Pharmaceutical Preparations, Medical Devices and Medical Consumables; and b. clinical pharmacy service. The success of the hospital in carrying out its functions is influenced by several factors, among which the most dominant is human resources. There are still few clinical pharmacy activities in Indonesia due to obstacles including lack of technical knowledge, lack of communication skills, work group pressure / work discomfort, lack of motivation and desire to change, lack of confidence, and lack of training in appropriate work flows, increased perceptions about the responsibility for the lack of staff in the Pharmacy Installation.

The success of hospitals in carrying out their functions is influenced by several factors, among which the most dominant is human resources. There are still few clinical pharmacy activities in Indonesia because there are obstacles, including lack of technical knowledge, lack of communication skills, work group pressure/work discomfort, lack of motivation and desire to change, lack of confidence, and lack of training in appropriate work flows, increased perceptions about the responsibility for the lack of staff in Pharmaceutical Installations (Rusli, 2018). The fulfillment of human resources is important for an institution or company. Excess power causes the cost burden to be large and inefficient in financial management. While the shortage of manpower will increase the workload of human resources which can affect the quality of service (Beswick S, 2010). At this time, health systems in various countries are always required to improve the quality of services and the degree of public health. The quality of these services will have an impact on patient safety due to employee negligence during the service process. One form of medical error factor that often occurs is errors in treatment ranging from the process to the use of drugs at the doses and medications given and some errors also occur in the wrong form of medication at the time of prescribing, reading prescriptions, errors in dispensing, and errors during delivery. (Kalra J, 2013).

One form of health human resource planning is pharmaceutical installation personnel planning. The availability of pharmaceutical human resources in addition to following existing regulations must also adjust to the needs of the hospital. So it needs proper HR planning according to your needs. HR needs are based on workload, this is to determine work capacity so that a balance between labor and workload is obtained (Dessler, G 2003). Because of this background, the researcher wanted to carry out an analysis and evaluation of the needs of pharmacists using the WISN method in the Pharmacy Installation of the Surabaya Haji Hospital. Surabaya Haji Hospital is a hospital owned by the government of East Java Province which was established in connection with the events that befell Indonesian Haji pilgrims in the Mina tunnel in 1990. From the description above, the Surabaya Haji Hospital, especially the Pharmacy Installation, is the right place to examine accurate calculations regarding workload and the need for pharmacists to support the service activities of the Pharmacy Installation, so that service quality standards can be fully achieved.

RI Minister of Health Decree No. 81 / Menkes / SK / I / 2004 concerning Guidelines for Health Human Resources Planning at Provincial, Regency / City and Hospital Levels are guidelines used to plan the provision and needs of human resources in health service institutions. Based on these guidelines, one of the recommended methods for measuring HR needs is using the WISN (Workload Indicators of Staffing Need) method, the Ministry of Health adopts a method of calculating the needs of labor based on the workload carried out by each category of human resources, namely the WISN (Work Indicator) method. of Staffing Need). This method in Indonesia is used to calculate the total needs of each category of health personnel required at the provincial, district / city health offices and hospitals and has been legalized through the Decree of the Minister of Health of the Republic of Indonesia No. 81 / Menkes / SK / 2004, the method of calculating needs based on workload (WISN) is an indicator that shows the size of the need for personnel in health facilities based on workload, so that the allocation / relocation of labor will be easier and more rational. The advantages of this method are easy to operate, easy to use, technically easy to apply, comprehensive and realistic (Kemenkes, 2004). 


\section{LITERATURE REVIEW}

Description Of The Services Section Workload At University Hospital Pharmaceutical Installation North Sumatra (Savitri Nugrahayati, 2018). The research knowing the description of the workload of service employees at the Installation North Sumatra University Hospital Pharmacy in terms of activities workforce which includes productive, non-productive and personal activities. type of descriptive observational research with qualitative data analysis, work sampling method. Sample on research service officer at Installation Hospital Pharmacy, University of North Sumatra. Results on research Workload at the Pharmacy Installation of the University of North Sumatra Hospital has not exceeded the optimum standard of $80 \%$, with the percentage of productive activities of $75.05 \%$. But if viewed per-shift, the average percentage of activities productive in shift I reached $87.24 \%$, shift II $84.52 \%$, and shift III $62.12 \%$.

Analysis Of Nurse Needs With Methods Workload Indicator Staffing Need (Wisn) In Installation Internal Department Rsd Dr. Soebandi Jember (Ari Purwanto, 2011). The research to find out the optimal amount of energy requirement nurse at the Internal Inpatient Unit of RSD Dr. Soebandi by load real work with the WISN method. Research method descriptive research with quantitative data analysis with work sampling method. Sample on research is power nurse. Results on research productive use of time from the total amount of working time available is $76.5 \%$. With activity details direct productive is $26.16 \%$, indirect productive is $37.19 \%$, and non-functional by $13.12 \%$. While the number of workers in the care installation stay in the internal section of the RSD Dr. Soebandi Jember based on the WISN method is 25 nurses.

Analysis of Psychiatric Needs Based on Workload Using Method of Workload Indicator Staffing Needs (WISN) in Mental Outpatient Unit Ernaldi Bahar Hospital, South Sumatra Province (Nurul Firiah, 2015). The research knowing how big is the workload and the number of needs medical personnel in the mental care unit of the hospital Ernaldi Bahar, South Sumatra Province Year 2015. Research method descriptive quantitative research with a crosssectional design using the method Workshops. Sample on research Psychiatrist at Inpatient Unit Jalan Jiwa Ernaldi Bahar Hospital. The results of the analysis show that the available working time of a psychiatrist is 97,920 minutes per year, Standard workload for patient assessment is 12,240, consultation is 19,548 , diagnosis and therapy is 97,920 and signature patient blank is 979200 . The standard of allowance takes 0.199 or $19.9 \%$. Based on the calculation method WISN needed as many as 6 psychiatrists available, 3 people (WISN ratio <1) workload tall.

\section{METHOD (FOR RESEARCH ARTICLE)}

This research is a descriptive observational research with qualitative data analysis with purposive sampling method, namely the sampling technique with certain criteria (Sugiyono, 2007). used for the Analysis and Evaluation of the Need for Pharmacists with the WISN Method in the Pharmacy Installation of the Surabaya Haji Hospital.
Various activities were carried out to collect existing data through observations using the work sampling method, indepth interviews with informants, and review of documents provided by the Haji Hospital Surabaya Pharmacy Installation. With the work sampling technique, all service department employee activities are observed every 5 minutes for 14 days. In this study, what is seen is the quantity of the portion of service employees, not the quality. From the results of the workload measurement, the results of the workload of the pharmacist section of the service section of the Haji Hospital Surabaya Pharmacy Installation will be obtained.

Activities of pharmacists in the service section of the Pharmacy Installation of the Haji Hospital Surabaya. variables and because what the researcher observes is the activity of the pharmacist in the service department and not its performance, therefore the researcher uses the work sampling method in carrying out activities so that the activities carried out can be represented in this study. The work sampling form used is the form that has been used by previous researchers (Herwina, 2017) and (Karina, N 2012).

\section{RESULTS AND DISCUSSION}

There are twenty personnel at the Pharmacy Installation of the Surabaya Haji Hospital with a composition of eighteen permanent pharmacists and two volunteer pharmacists. Each pharmacist in the Pharmacy Installation of the Surabaya Haji Hospital has different characteristics from one another in terms of position level, education level, gender and length of work. In this study, there were eighteen informants who were willing to be interviewed.

\section{[Table 1 about here.]}

\section{Establishing Available Working Time}

The working time available for pharmacists at the Haji Hospital Surabaya Pharmacy Installation is the working time that should be fulfilled by the pharmacist in carrying out their main activities in the Pharmacy Installation at the Haji Hospital Surabaya for one year. The available working time formulas are:

Available Working Time $=\{\mathrm{A}-(\mathrm{B}+\mathrm{C}+\mathrm{D}+\mathrm{E})\} \times \mathrm{E}$

\section{Based on this formula, the working time provided for}

Pharmacists at the Haji Hospital Surabaya Pharmacy Installation is calculated from working days for one year minus annual leave days for, education and training according to hospital policy, national holidays set by the government, personnel absence from work. within one year and multiplied by the length of time working a day at the Haji Hospital Surabaya Pharmacy Installation, the result is 97920 minutes / year or 1632 hours / day or 204 effective working days for one year. 
[Table 7 about here.]

Based on the calculation table above, it is known that the WISN ratio of personnel requirements at the Surabaya Haji Hospital Pharmacy Installation is 0.83 which means that the current number of pharmacists at the Registration Counter is smaller than the required number of personnel needed to complete the existing workload. So to achieve a balanced state, it is necessary to increase the number of pharmacists in the Pharmacy Installation of the Haji Hospital Surabaya as many as 4 out of 20 people who are currently there.

\section{Discussion}

\section{Pharmacy service activities at the Pharmacy Installation of Haji Hospital Surabaya using the WISN method}

This study uses a purposive sampling method, namely the sampling technique by determining certain criteria (Sugiyono, 2008). Researchers could not directly observe the work carried out by pharmacists because this research was carried out during the covid-19 pandemic, so this research was carried out using voice notes on the WhatsApp application that was used for interviews, then triangulation of sources was carried out directly with the Head of the Home Pharmacy Installation. Surabaya Haji Hospital by implementing strict health protocols. In the interview process in the study, it is feared that there will be bias in the study because pharmacists feel they are not observed directly due to the limitations of researchers in the Covid-19 pandemic so that interviews are conducted using the WhatsApp application, pharmacists have a tendency to answer as well as possible. To minimize this, when formulating the results, researchers are not only based on the answers of one pharmacist but also take answers that the majority say the same so that the results are more objective. Observations prioritize activities or activities carried out by personnel, the results of observations on form work sampling are then categorized into direct productive activities, indirect productive activities, unproductive activities and personal activities.

\section{Establishing Available Working Time}

The working time available at the Pharmacy Installation of Haji Hospital Surabaya in one year is 240 working days or 1632 hours per year. The variable for calculating the available working time is obtained from the total number of working days in one year minus the number of holidays set by the government, namely 20 national holidays, 12 days of annual leave, 1 day of education and training and the average absence from work in a year is 3 days.

The result of working time available at the Pharmacy Installation of Haji Hospital Surabaya in one year is 240 working days or 1632 hours per year which is calculated using various existing variables, namely from the total number of working days in one year and minus the number of holidays set by the government on In 2020, there are 20 national holidays and then 12 days of annual leave and 1 day of education and training and the average absence from work in a year is 3 days so that the result is 240 working days or
1632 hours per year. The result of determining working time serves to calculate the next formula in the standard workload section which is the result of measuring the available working time compared to the average time needed to complete each main activity and then also functions in calculating the standard allowance, which is the time required to complete each main activity. carry out other activities that are not directly related but are still useful for existing personnel personil.

Determine the work unit and category of HR under study

The category of HR that will be calculated for the needs of the workforce is the Pharmacist at the Pharmacy Installation of Haji Hospital Surabaya. As a health service provider who is very busy, it is very important to know how the workload carried out at the Pharmacy Installation of the Haji Hospital Surabaya is as a provider of pharmaceutical services to patients who are carrying out treatment at the Haji Hospital Surabaya.

\section{Use of Working Time Based on Work Sampling}

Observation of the use of time patterns in each pharmacist activity at the Pharmacy Installation of Haji Hospital Surabaya is preceded by looking at the characteristics of all activities that have been observed and then grouped into each activity pattern (Barnes, 1980). Where the number of groups of activity patterns can be combined according to research needs (Ilyas, 2013). In this study the pattern of activities is divided into direct productive activities, indirect productive activities, unproductive activities and personal activities. Furthermore, by getting the amount of productive working time of Pharmacists at the Pharmacy Installation of Haji Hospital Surabaya, it will be able to calculate the optimal need for pharmacists based on the WISN calculation formula. In accordance with the results of the study using the work sampling method, it was obtained that the pharmacist at the Pharmacy Installation of Haji Hospital Surabaya for fourteen days of observation using the WhatsApp application, $64.84 \%$ of the time was productive directly, because it was used to carry out activities directly related to services, other used for indirect productive activities by $11.80 \%$, then for non-productive activities by $8.09 \%$ and use of time for personal activities by $15.24 \%$.

The distribution of time for direct productive activities at the Pharmacy Installation of Haji Hospital Surabaya is mostly in clinical pharmacy service activities, namely visits to the inpatient room as many as 46,628 times requiring an average time of 2100 minutes, dispensing and drug counseling as much as 65.28 times requiring average time is 1500 minutes, evaluation of drug use is 90,666 times requiring an average time of 1080 minutes, selection and procurement is 29,142 times requiring an average time of 3360 minutes. Based on the results of interviews, if one pharmacist is not present, it will increase the workload in the service and affect the longer service time so that pharmacists need help from other parts to help ease the work in services at the Pharmacy Installation of Haji Hospital Surabaya.

\section{Develop Workload Standards}

In accordance with the table on the standard workload based on observation activities at the Pharmacy Installation 
of Haji Hospital Surabaya, it has different values for each productive activity carried out. To find out the average time needed to complete the main activities obtained from observations reinforced by interviews with all personnel. The highest standard of workload based on calculations is in the activity of serving visits to the inpatient room as much as 46,628 times and takes 2100 minutes/year.

\section{Establish Allowance Standards}

The standard of leniency at the Pharmacy Installation of Haji Hospital Surabaya is certainly different in each hospital, influenced by the number of patient visits and policies in each unit. The standard of slack for personnel at the Pharmacy Installation of the Haji Hospital Surabaya is obtained from the time required to complete activities that are not directly related to the main or productive activities of the service, the result is that the total standard of allowance at the Pharmacy Installation of the Haji Hospital Surabaya is 0.118

\section{Labor Needs in the Pharmacy Installation of the Haji Hospital Surabaya}

Calculation of the need for personnel in the Pharmacy Installation of Haji Hospital Surabaya based on the WISN method results in a calculation of the number of pharmacists needed for 24 people, compared to the number of pharmacists currently being 20 pharmacists, the increase in the number of pharmacists is 4 people in the Pharmacy Installation of Haji Hospital Surabaya. The current amount of energy fulfillment from the new calculation meets $83 \%$ of the ideal amount produced by the WISN method. With the obstacles faced in the Pharmacy Installation of Haji Hospital Surabaya, such as the large workload of clinical pharmacy services that are carried out every day. To anticipate this, it is necessary to fulfill the need for pharmacists according to the workload.

\section{Gap Ratio of Pharmacists in the Pharmacy Installation of the Haji Hospital Surabaya}

From the results of the calculation of the number of personnel at the Pharmacy Installation of Haji Hospital Surabaya, the results obtained are 24 people, while the current workforce is 20 people. The ratio of pharmacists in the Pharmacy Installation of Haji Hospital Surabaya was obtained based on the WISN ratio of 0.81 .

In the WISN User's Manual (WHO, 2010) it is explained that if the power ratio is one, it means that the number of workers is in accordance with the demands of the workload (the number of workers is sufficient). The value of the ratio is less than one, it means that the amount of power is not in accordance with the workload (less power) and if the value is more than one, it indicates the amount of excess power in relation to the workload. The smaller the WISN ratio, the greater the workload. Based on this, it means that the number of staff at the Registration Counter for BPJS participants is currently not in accordance with the existing workload. The existing workload is greater than the amount of available power. Considerations for the management of the Pharmacy Installation of the Haji Hospital Surabaya are planning the need or addition of pharmacists which means also reducing the pressure due to the high workload for pharmacists at the Pharmacy Installation of the Haji Hospital Surabaya and at the same time as an effort to improve the quality of service.

\section{Pharmacist Recruitment Process at the Pharmacy Installation of Haji Hospital Surabaya}

The process of recruiting pharmacists at the Pharmacy Installation of Haji Hospital Surabaya is carried out by the Head of the Pharmacy Installation submitting an application to the Director of the Surabaya Hajj Hospital and forwarded to the Regional Personnel Agency to determine the number of pharmacists needed by the Surabaya Hajj Hospital Pharmacy Installation and then by BLUD, namely employees honorary. The CSSD at Haji Hospital Surabaya stands as a separate installation so that the work process is not included in the Pharmacy Installation.

\section{CONCLUSIONS}

1. Pharmaceutical service activities carried out by pharmacists in productive activities with pharmaceutical activities that have a workload that is greater than other direct productive activities.

2. Job descriptions of Pharmacists at the Surabaya HajI Hospital Pharmacy Installation with the highest workload based on calculations are found in the Pharmacist's task when serving visites to the ward.

3. The workload of Pharmacists at the Surabaya Hajj Hospital Pharmacy Installation in the early days of the Covid-19 pandemic decreased slightly due to the situation of the number of general patients at the Surabaya Haji Hospital has decreased, but from January 2021 until now the patient has increased again so that the workload of Pharmacists has returned to normal such as before the pandemic, the workload was heavier so that the addition of the number of pharmacists is needed by the Surabaya Hajj Hospital Pharmacy Installation to improve the quality of pharmaceutical services.

\section{ACKNOWLEDGEMENT}

We would like to thank Strada Indonesia Institute of Science for the learning opportunities provided to the opportunity for the thesis research provided and the Haji Hospital Surabaya for the opportunities and research places provided to researchers. 


\section{REFERENCES}

Adawiyah, W. 2013. Analisis Beban Kerja Sumber Daya Manusia Dalam Aktivitas Produksi Komoditi Sayuran Selada (Studi Kasus: CV Spirit Wira Utama). Skripsi pada Fakultas Ekonomi dan Manajemen, Institut Pertanian Bogor, Bogor.

Andini, Sarah. Analisi Kebutuhan Tenaga Keperawatan di Hemodialisa RSUP Persahabatan Berdasarkan Beban dan Kompetensi Kerja. Tesis. Fakultas Kesehatan Masyarakat, Universitas Indonesia, Depok. 2013

Badriah, F. (2015). Pengungkapan Kesalahan Medis Disclossing Medical Error for Safety Patient Culture. Jakarta: UIN Press: hal. 7-8.

Beswick S, Hill PD, and Anderson MA. Comparison of Nurse Workload Approaches. Journal of Nursing Management. 2010; 18(5): 592-598

Darmayanti. (2016). Analisis Produktivitas Kerja Karyawan Dikaitkan dengan Time Management.Jurnal Akuisisi. 4(1): hal 3-4.

Depkes RI. (2014). Peraturan Menteri Kesehatan Republik Indonesia Nomor 56 tahun 2014 tentang Klasifikasi dan Perizinan Rumah Sakit. Jakarta: Departemen Kesehatan RI: hal. 3-8; 28-30.

Depkes RI. (2016). Peraturan Menteri Kesehatan Republik Indonesia Nomor 72 Tahun 2016 tentang Standar Pelayanan Kefarmasian di Rumah Sakit.Jakarta: Departemen Kesehatan RI: hal. 46.

Dessler G. Manajemen Sumber Daya Manusia. In: Pelatihan Dan Pengembangan. ; 2017. doi:10.1145/2505515.2507827

Dewi, U. dan Satrya, A. 2012. Analisis Kebutuhan Tenaga Kerja Berdasarkan Beban Kerja Karyawan Pada PT PLN (Persero) Distribusi Jakarta Raya dan Tangerang Bidang Sumber Daya Manusia dan Organisasi. Jurusan Manajemen SDM Fakultas Ekonomi Universitas Indonesia, Depok. ------, http://www.aisi.or.id/statistic/ diakses pada tanggal 9 September 2013.

Hendianti GN. Gambaran Beban Kerja Perawat Pelaksana Unit Instalasi Gawat Darurat Rumah Sakit Muhammadiyah Bandung. Students e-Journal. 2012.

Haliman dan Wulandari. 2012. Cerdas Memilih Rumah Sakit. Yogyakarta: CV. Andi Offset.

Herwina, Dara. (2017). Gambaran Beban Kerja Tenaga Asisten Apoteker di Instalasi Farmasi Rumah Sakit Umum (RSU) Kota Tangerang Selatan Tahun 20017. Skripsi. Universitas Islam Negeri Syarif Hidayatullah: hal. 83-94.

Ilyas, Yaslis. (2011). Perencanaan SDM Rumah Sakit, Teori, Metoda dan Formula. Depok: Fakultas Kesehatan Masyarakat Universitas Indonesia: hal. 28; 48-50; 246; 248-251.

Ilyas. Yaslis. Perencanaan SDM Rumah Sakit: Teori, Metoda dan Formula. Fakultas Kesehatan Masyarakat, Universitas Indonesia, Depok. 2013

Irmawati, L.I. (2014). Manajemen Logistik Farmasi di Rumah Sakit. Surabaya: Penerbit Universitas Airlangga: hal. 31

Kalra J, Kalra N, Baniak N. Medical error, disclosure and patient safety: A global view of quality care. Clin Biochem. 2013. doi:10.1016/j.clinbiochem.2013.03.025

Karina, N. (2012). Gambaran Beban Kerja Pegawai di Instalasi Farmasi Rumah Sakit Hasanah Graha Afiah. Skripsi. Fakultas Kesehatan Masyarakat Universitas Indonesia. hal: 297-213.

Malano, A. Fazani. Analisis Beban Kerja Petugas TPPRJ RSUD Tugurejo Semarang Berdasarkan Metode Wisn Pada Tahun 2015. Skripsi. Fakultas Kesehatan Masyarakat, Universitas Dian Nuswantoro, Semarang. 2015

Moleong, j, Lexy. 2013. Metodologi Penelitian Kualitatif. Bandung: PT. Remaja Rosdakarya.

Nuryati -, Pramono AE, Wijayanti A. Perencanaan Kebutuhan Tenaga Rekam Medis Dengan Metode Workload Indicators Of Staffing Need (WISN) Dipuskesmas Gondokusuman II Kota Yogyakarta. J Manaj Inf Kesehat Indones. 2013. doi: $10.33560 / . v 1 \mathrm{i} 2.44$ 
Patuwo, Benny. Analisis Kebutuhan Tenaga Analis di Unit Laboratorium Pelayanan Kesehatan St. Carolus Tahun 2005. Thesis Program Pascasarjana Fakultas Kesehatan Masyarakat, Universitas Indonesia, Depok. 2005

Perkins. Work Sampling: A Method for Assesing and Monitoring Productivity. The Bussinessowner Journal. West Sacramento. 2009

Peraturan Menteri Kesehatan (Permenkes atau PMK) nomor 3 Tahun 2020

Peraturan Menteri Kesehatan (Permenkes atau PMK) nomor 30 Tahun 2019

Peraturan Menteri Kesehatan (Permenkes atau PMK) nomor 72 tahun 2016

Rikomah, S.E. (2017). Farmasi Klinik. Yogyakarta: Deepublish: hal. 34-37.

Rusli. Farmasi Klinik. Kementeri Kesehat Republik Indones. 2018.

Sugiyono. (2017). Metode Penelitian Kuantitatif, Kualitatif, dan R\&D. Bandung: Alfabeta, CV.

Syukraa, HG. Analisis Kebutuhan Tenaga Berdasarkan Beban Kerja dengan Teknik Work Sampling Menggunakan Metode WISN di Unit Farmasi Rawat Jalan Krakatau Medikal Hospital Cilegon tahun 2012. Tesis. Fakultas Kesehatan Masyarakat, Universitas Indonesia, Depok. 2012

Thoe, D.A. (2013). Opini Apoteker dan Pasien terhadap Peran Apoteker dalam Pelayanan Kefarmasian di Apotek Kota Merauke.Jurnal Mahasiswa Universitas Surabaya.1(1): hal. 2-3.

Conflict of Interest Statement: The authors declare that the research was conducted in the absence of any commercial or financial relationships that could be construed as a potential conflict of interest.

Copyright (C) tahun terbit nama belakang and nama belakang. This is an openaccess article distributed under the terms of the Creative Commons Attribution License (CC BY). The use, distribution or reproduction in other forums is permitted, provided the original author(s) and the copyright owner(s) are credited and that theoriginal publi-cation in this journal is cited, in accordance with accepted academic practice. No use, distribution or reproduction is permitted which does not comply with these terms. 


\section{LIST OF TABLES}

1 Description of the Characteristics of Pharmacists in the Pharmacy Installation of the Haji Hospital Surabaya .......277

2 Available Working Hours of Pharmacist in One Year at the Pharmacy Installation of the Haji Hospital Surabaya 278

3 Total Activity of Pharmacist by Type of Activity in Minutes ..................................................................278

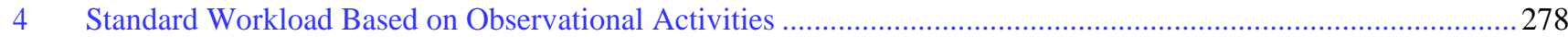

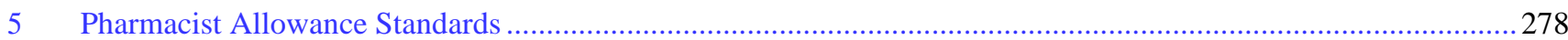

6 The Need for Personal in the Pharmacy Installation of the Haji Hospital Surabaya with the WISN Method...........278

$7 \quad$ The gap between the existing power and the needs of the results of the WISN analysis .....................................279 
TABLE 1 | Description of the Characteristics of Pharmacists in the Pharmacy Installation of the Haji Hospital Surabaya

\begin{tabular}{|c|c|c|c|c|}
\hline No. & Position & Education & Gender & $\begin{array}{l}\text { Length of } \\
\text { working }\end{array}$ \\
\hline 1 & Head of Pharmacy Installation & $\begin{array}{l}\text { Pharmacist } \\
\text { Profession } \\
\text { Apoteker dan }\end{array}$ & Male & 21 Years \\
\hline 2 & Pharmacist & $\begin{array}{l}\text { Magister Farmasi } \\
\text { Klinik }\end{array}$ & Female & 25 Years \\
\hline 3 & Pharmacist & $\begin{array}{l}\text { Pharmacist } \\
\text { Profession }\end{array}$ & Female & 7 Years \\
\hline 4 & Pharmacist & $\begin{array}{l}\text { Pharmacist } \\
\text { Profession }\end{array}$ & Female & 7 Months \\
\hline 5 & Pharmacist & $\begin{array}{l}\text { Pharmacist } \\
\text { Profession }\end{array}$ & Female & 1 Year 9 Months \\
\hline 6 & Pharmacist & $\begin{array}{l}\text { Pharmacist } \\
\text { Profession }\end{array}$ & Female & 26 Years \\
\hline 7 & Pharmacist & $\begin{array}{l}\text { Pharmacist } \\
\text { Profession }\end{array}$ & Female & 7 Months \\
\hline 8 & Pharmacist & $\begin{array}{l}\text { Pharmacist } \\
\text { Profession }\end{array}$ & Female & 2 Years \\
\hline 9 & Pharmacist & $\begin{array}{l}\text { Pharmacist } \\
\text { Profession }\end{array}$ & Female & 6 Years \\
\hline 10 & Pharmacist & $\begin{array}{l}\text { Pharmacist } \\
\text { Profession }\end{array}$ & Female & $\begin{array}{l}2 \text { Years } 8 \\
\text { Months }\end{array}$ \\
\hline 11 & $\begin{array}{l}\text { Pharmacist Department of } \\
\text { Isolation Room Clinical }\end{array}$ & $\begin{array}{l}\text { Pharmacist } \\
\text { Profession }\end{array}$ & Female & 10 Years \\
\hline 12 & $\begin{array}{l}\text { Pharmacist Department of } \\
\text { Logistics Warehouse }\end{array}$ & $\begin{array}{l}\text { Pharmacist } \\
\text { Profession }\end{array}$ & Male & 10 Years \\
\hline 13 & Pharmacist & $\begin{array}{l}\text { Pharmacist } \\
\text { Profession }\end{array}$ & Female & 6 Years \\
\hline 14 & Pharmacist & $\begin{array}{l}\text { Pharmacist } \\
\text { Profession }\end{array}$ & Female & 10 Years \\
\hline 15 & $\begin{array}{l}\text { Pharmacist Department of } \\
\text { Procurement }\end{array}$ & $\begin{array}{l}\text { Pharmacist } \\
\text { Profession }\end{array}$ & Female & $\begin{array}{l}6 \text { Years } 8 \\
\text { Months }\end{array}$ \\
\hline 16 & Pharmacist & $\begin{array}{l}\text { Pharmacist } \\
\text { Profession }\end{array}$ & Male & 11 Years \\
\hline 17 & Volunteer Pharmacist & $\begin{array}{l}\text { Pharmacist } \\
\text { Profession }\end{array}$ & Male & 1 Years \\
\hline 18 & Pharmacist & $\begin{array}{l}\text { Pharmacist } \\
\text { Profession }\end{array}$ & Female & 1 Years \\
\hline
\end{tabular}


TABLE 2 | Available Working Hours of Pharmacist in One Year at the Pharmacy Installation of the Haji Hospital Surabaya

\begin{tabular}{rlcl}
\hline Code & \multicolumn{1}{c}{ Factor } & Amount & Information \\
\hline A & Working days & 240 & day / year \\
B & Annual leave & 12 & day / year \\
C & Education and Training & 1 & day / year \\
D & National holiday & 20 & day / year \\
E & Average absence from work & 3 & day / year \\
F & Working time & 8 & hour / day \\
& Total working days = [A-(B+C+D+E)] & 204 & day / year \\
& Available working time= [A-(B+C+D+E)]Xf & 1632 & hour / day \\
& Total Runtime in minutes & 97920 & minutes / year \\
\hline
\end{tabular}


TABLE 3 | Total Activity of Pharmacist by Type of Activity in Minutes

\begin{tabular}{|c|c|c|c|}
\hline Activities & & T(minute) & $\%$ \\
\hline Productive Direct & Activity Item & & \\
\hline \multirow[t]{8}{*}{ Preparation of a pharmaceutical work plan } & Prepare an activity plan & 240 & $0,221 \%$ \\
\hline & Election & 960 & $0,886 \%$ \\
\hline & Planning & 480 & $0,443 \%$ \\
\hline & Procurement & 5760 & $5,321 \%$ \\
\hline & Central Sterilization & 0 & $0,000 \%$ \\
\hline & Test the quality of raw materials & 0 & $0,000 \%$ \\
\hline & $\begin{array}{l}\text { Test the quality of finished drug } \\
\text { preparations }\end{array}$ & 0 & $0,000 \%$ \\
\hline & Make quality test recommendations & 0 & $0,000 \%$ \\
\hline \multirow[t]{11}{*}{ Management of pharmaceutical supplies } & Penerimaan & 480 & $0,443 \%$ \\
\hline & Storage & 120 & $0,110 \%$ \\
\hline & Distribution & 120 & $0,110 \%$ \\
\hline & Deletion & 120 & $0,110 \%$ \\
\hline & $\begin{array}{l}\text { Preparation of reports on the } \\
\text { management of pharmaceutical } \\
\text { supplies }\end{array}$ & 2880 & $2,660 \%$ \\
\hline & $\begin{array}{l}\text { Evaluation of pharmaceutical supply } \\
\text { management activities }\end{array}$ & 2880 & $2,660 \%$ \\
\hline & Dispensing & 8640 & $7,982 \%$ \\
\hline & Visite to the ward & 2880 & $2,660 \%$ \\
\hline & Drug information service & 720 & $0,665 \%$ \\
\hline & Drug counseling & 2400 & $2,217 \%$ \\
\hline & $\begin{array}{l}\text { Consultation with doctors, nurses } \\
\text { and other health professionals }\end{array}$ & 4800 & $4,434 \%$ \\
\hline \multirow{7}{*}{ Clinical pharmacy services } & Evaluate drug use & 2880 & $2,660 \%$ \\
\hline & Drug side effect monitoring & 540 & $0,498 \%$ \\
\hline & Monitoring drug levels in the blood & 0 & $0,000 \%$ \\
\hline & Analyze cost effectiveness & 60 & $0,055 \%$ \\
\hline & $\begin{array}{l}\text { Preparation of clinical pharmacy } \\
\text { reports }\end{array}$ & 1440 & $1,330 \%$ \\
\hline & $\begin{array}{l}\text { Long distance pharmaceutical } \\
\text { services }\end{array}$ & 120 & $0,110 \%$ \\
\hline & Home care & 0 & $0,000 \%$ \\
\hline \multirow[t]{4}{*}{ Special Pharmacy Services } & Ambulatory services & 0 & $0,000 \%$ \\
\hline & Swamedikasi & 0 & $0,000 \%$ \\
\hline & Palliative care & 0 & $0,000 \%$ \\
\hline & $\begin{array}{l}\text { Outbreaks of plague / natural } \\
\text { disasters }\end{array}$ & 0 & $0,000 \%$ \\
\hline Community dedication & $\begin{array}{l}\text { Occupational Health and Safety (K- } \\
\text { 3) }\end{array}$ & 0 & $0,000 \%$ \\
\hline $\begin{array}{l}\text { Performing tasks in places that are high risk or } \\
\text { vulnerable }\end{array}$ & $\begin{array}{l}\text { Carrying out tasks in a place that has } \\
\text { a high risk and / or prone }\end{array}$ & 28800 & $26,607 \%$ \\
\hline $\begin{array}{l}\text { Become a witness in the deletion of } \\
\text { pharmaceutical supplies and / or documents } \\
\text { thereof }\end{array}$ & $\begin{array}{l}\text { Become a witness in the deletion of } \\
\text { pharmaceutical supplies and / or } \\
\text { documents thereof }\end{array}$ & 0 & $0,00 \%$ \\
\hline Leading the work unit & Leading the work unit & 2880 & $2,660 \%$ \\
\hline Sub Total & & 70200 & $64,84 \%$ \\
\hline \multicolumn{4}{|l|}{ Productive Indirect } \\
\hline Drug defecta & & 2880 & $2,660 \%$ \\
\hline Tidy up work equipment & & 720 & $0,665 \%$ \\
\hline Tidy up work documents & & 720 & $0,665 \%$ \\
\hline $\begin{array}{l}\text { Tidy up and store medicines / medical } \\
\text { equipment }\end{array}$ & & 60 & $0,055 \%$ \\
\hline
\end{tabular}


Take the medicine from the warehouse

$\begin{array}{cc}480 & 0,443 \% \\ 240 & 0,221 \% \\ 360 & 0,332 \% \\ 3000 & 2,771 \% \\ 1440 & 1,330 \% \\ 2880 & 2,660 \% \\ & \\ \mathbf{1 2 7 8 0} & \mathbf{1 1 , 8 0 \%}\end{array}$

Sub total

12780

$11,80 \%$

\section{Not productive}

Call with private phone

$\begin{array}{cc}960 & 0,886 \% \\ 3000 & 2,771 \% \\ 3000 & 2,771 \% \\ 0 & 0,000 \% \\ 360 & 0,332 \% \\ 1440 & 1,330 \% \\ \mathbf{8 7 6 0} & \mathbf{8 , 0 9 \%}\end{array}$

Sub Total

876

$3000 \quad 2,771 \%$

Eat

$1500 \quad 1,385 \%$

Drink

$9000 \quad 8,314 \%$

Prayer

$3000 \quad 2,771 \%$

Toilet 
TABLE 4 | Standard Workload Based on Observational Activities

\section{Activities}

\begin{tabular}{|c|c|c|c|}
\hline Productive Direct & Activity Item & $\begin{array}{l}\text { Average time per } \\
\text { activity }\end{array}$ & $\begin{array}{l}\text { Standard } \\
\text { Workload }\end{array}$ \\
\hline \multirow{7}{*}{$\begin{array}{l}\text { Preparation of a } \\
\text { pharmaceutical work plan }\end{array}$} & Prepare an activity plan & 1200 & 81,6 \\
\hline & Election & 3360 & 29,142 \\
\hline & Planning & 60 & 1632 \\
\hline & Procurement & 3360 & 29,142 \\
\hline & Central Sterilization & 0 & 0 \\
\hline & Test the quality of raw materials & 0 & 0 \\
\hline & $\begin{array}{l}\text { Test the quality of finished drug } \\
\text { preparations }\end{array}$ & 0 & 0 \\
\hline \multirow{12}{*}{$\begin{array}{l}\text { Management of } \\
\text { pharmaceutical supplies }\end{array}$} & Make quality test recommendations & 0 & 0 \\
\hline & Penerimaan & 600 & 163,2 \\
\hline & Storage & 600 & 163,2 \\
\hline & Distribution & & \\
\hline & Deletion & 720 & 136 \\
\hline & $\begin{array}{l}\text { Preparation of reports on the management } \\
\text { of pharmaceutical supplies }\end{array}$ & 720 & 136 \\
\hline & $\begin{array}{l}\text { Evaluation of pharmaceutical supply } \\
\text { management activities }\end{array}$ & 720 & 136 \\
\hline & Dispensing & 1500 & 65,28 \\
\hline & Visite to the ward & 2100 & 46,628 \\
\hline & Drug information service & 300 & 326,4 \\
\hline & Drug counseling & 1500 & 65,28 \\
\hline & $\begin{array}{l}\text { Consultation with doctors, nurses and } \\
\text { other health professionals }\end{array}$ & 900 & 108,8 \\
\hline \multirow{7}{*}{ Clinical pharmacy services } & Evaluate drug use & 1080 & 90,666 \\
\hline & Drug side effect monitoring & 50 & 1958,4 \\
\hline & Monitoring drug levels in the blood & 0 & 0 \\
\hline & Analyze cost effectiveness & 0 & 0 \\
\hline & Preparation of clinical pharmacy reports & 720 & 136 \\
\hline & Long distance pharmaceutical services & 15 & 6528 \\
\hline & Home care & 0 & 0 \\
\hline \multirow[t]{4}{*}{ Special Pharmacy Services } & Ambulatory services & 0 & 0 \\
\hline & Swamedikasi & 15 & 6528 \\
\hline & Palliative care & 0 & 0 \\
\hline & Outbreaks of plague / natural disasters & 0 & 0 \\
\hline Community dedication & Occupational Health and Safety (K-3) & 0 & 0 \\
\hline $\begin{array}{l}\text { Performing tasks in places that } \\
\text { are high risk or vulnerable }\end{array}$ & $\begin{array}{l}\text { Carrying out tasks in a place that has a } \\
\text { high risk and / or prone }\end{array}$ & 1500 & 65,28 \\
\hline $\begin{array}{l}\text { Become a witness in the } \\
\text { deletion of pharmaceutical } \\
\text { supplies and / or documents } \\
\text { thereof }\end{array}$ & $\begin{array}{l}\text { Become a witness in the deletion of } \\
\text { pharmaceutical supplies and / or } \\
\text { documents thereof }\end{array}$ & 0 & 0 \\
\hline Leading the work unit & Leading the work unit & 2880 & 34 \\
\hline
\end{tabular}


TABLE 5 / Pharmacist Allowance Standards

\begin{tabular}{lcccc}
\hline \multicolumn{1}{c}{ Activities } & $\begin{array}{c}\text { Duration of } \\
\text { activity } \\
\text { (minute) }\end{array}$ & $\begin{array}{c}\text { Frequency } \\
\text { per year }\end{array}$ & $\begin{array}{c}\text { Total needs } \\
\text { time } \\
\text { (minutes) }\end{array}$ & Pharmacist Needs \\
\hline $\begin{array}{l}\text { Count the narcotics stock } \\
\text { Psychotropics }\end{array}$ & 30 & 12 & 360 & 0,003 Pharmacist \\
$\begin{array}{l}\text { Input reports } \\
\text { psychotropic narcotics }\end{array}$ & 30 & 12 & 360 & 0,003 Pharmacist \\
Recap monthly reports & 30 & 12 & 360 & 0,003 Pharmacist \\
Monthly recitation & 0 & 0 & 0 & 0,000 Pharmacist \\
Stock opname & 300 & 12 & 3600 & 0,036 Pharmacist \\
Coordination briefing & 10 & 30 & 3000 & 0,030 Pharmacist \\
Meeting & 60 & 0 & 2880 & 0,029 Pharmacist \\
education and training & 120 & 12 & 1440 & 0,014 Pharmacist \\
Allowance Standards & & & & $\mathbf{0 , 1 1 8}$ Pharmacist \\
\hline
\end{tabular}


TABLE 6 / The Need for Personal in the Pharmacy Installation of the Haji Hospital Surabaya with the WISN Method

\begin{tabular}{|c|c|c|c|c|}
\hline Main Activities & Activity Item & $\begin{array}{c}\text { Quantity of } \\
\text { Main Activities }\end{array}$ & $\begin{array}{l}\text { Standard } \\
\text { Workload }\end{array}$ & Pharmacist Needs \\
\hline \multirow{7}{*}{$\begin{array}{l}\text { Preparation of a } \\
\text { pharmaceutical work plan }\end{array}$} & Prepare an activity plan & 240 & 81,6 & 2,941 \\
\hline & Election & 1 & 29,142 & 0,034 \\
\hline & Planning & 12 & 1632 & 0,007 \\
\hline & Procurement & 12 & 29,142 & 0,411 \\
\hline & Central Sterilization & 0 & 0 & 0 \\
\hline & Test the quality of raw materials & 0 & 0 & 0 \\
\hline & $\begin{array}{l}\text { Test the quality of finished drug } \\
\text { preparations }\end{array}$ & 0 & 0 & 0 \\
\hline \multirow{12}{*}{$\begin{array}{l}\text { Management of } \\
\text { pharmaceutical supplies }\end{array}$} & Make quality test recommendations & 0 & 0 & 0 \\
\hline & Penerimaan & 240 & 163,2 & 1,470 \\
\hline & Storage & 240 & 163,2 & 1,470 \\
\hline & Distribution & 0 & 0 & 0 \\
\hline & Deletion & 12 & 136 & 0,088 \\
\hline & $\begin{array}{l}\text { Preparation of reports on the } \\
\text { management of pharmaceutical } \\
\text { supplies }\end{array}$ & 12 & 136 & 0,088 \\
\hline & $\begin{array}{l}\text { Evaluation of pharmaceutical supply } \\
\text { management activities }\end{array}$ & 12 & 136 & 0,088 \\
\hline & Dispensing & 240 & 65,28 & 3,676 \\
\hline & Visite to the ward & 12 & 46,628 & 0,257 \\
\hline & Drug information service & 60 & 326,4 & 0,183 \\
\hline & Drug counseling & 240 & 65,28 & 3,676 \\
\hline & $\begin{array}{l}\text { Consultation with doctors, nurses } \\
\text { and other health professionals }\end{array}$ & 600 & 108,8 & 5,514 \\
\hline \multirow{7}{*}{ Clinical pharmacy services } & Evaluate drug use & 2 & 90,666 & 0,022 \\
\hline & Drug side effect monitoring & 5 & 1958,4 & 0,002 \\
\hline & Monitoring drug levels in the blood & 0 & 0 & 0 \\
\hline & Analyze cost effectiveness & 0 & 0 & 0 \\
\hline & $\begin{array}{l}\text { Preparation of clinical pharmacy } \\
\text { reports }\end{array}$ & 12 & 136 & 0,088 \\
\hline & $\begin{array}{l}\text { Long distance pharmaceutical } \\
\text { services }\end{array}$ & 120 & 6528 & 0,018 \\
\hline & Home care & 0 & 0 & 0 \\
\hline \multirow[t]{4}{*}{ Special Pharmacy Services } & Ambulatory services & 0 & 0 & 0 \\
\hline & Swamedikasi & 240 & 6528 & 0,036 \\
\hline & Palliative care & 0 & 0 & 0 \\
\hline & $\begin{array}{l}\text { Outbreaks of plague / natural } \\
\text { disasters }\end{array}$ & 0 & 0 & 0 \\
\hline Community dedication & $\begin{array}{l}\text { Occupational Health and Safety (K- } \\
\text { 3) }\end{array}$ & 0 & 0 & 0 \\
\hline $\begin{array}{l}\text { Performing tasks in places that } \\
\text { are high risk or vulnerable }\end{array}$ & $\begin{array}{l}\text { Carrying out tasks in a place that has } \\
\text { a high risk and / or prone }\end{array}$ & 240 & 65,28 & 3,676 \\
\hline $\begin{array}{l}\text { Become a witness in the } \\
\text { deletion of pharmaceutical } \\
\text { supplies and / or documents } \\
\text { thereof }\end{array}$ & $\begin{array}{l}\text { Become a witness in the deletion of } \\
\text { pharmaceutical supplies and / or } \\
\text { documents thereof }\end{array}$ & 0 & 0 & 0 \\
\hline \multirow[t]{3}{*}{ Leading the work unit } & Leading the work unit & 24 & 34 & 0,705 \\
\hline & & \multicolumn{2}{|c|}{$\begin{array}{l}\text { Number of Pharmacists } \\
\text { needed }\end{array}$} & 24,362 \\
\hline & & \multicolumn{2}{|c|}{ Allowance Standards } & $\begin{array}{l}0,118 \\
\text { Pharmacist } \\
24,48\end{array}$ \\
\hline
\end{tabular}


The amount of manpower at this time 
TABLE 7 / The gap between the existing power and the needs of the results of the WISN analysis

\begin{tabular}{|c|c|c|c|c|}
\hline $\begin{array}{c}\text { Existing } \\
\text { pharmacist (a) }\end{array}$ & $\begin{array}{c}\text { Pharmacist } \\
\text { Needs (b) }\end{array}$ & Less / More (a-b) & $\begin{array}{c}\text { WISN Ratio } \\
(\mathbf{a} / \mathbf{b})\end{array}$ & $\begin{array}{c}\text { Pharmacist's } \\
\text { Problem State }\end{array}$ \\
\hline 20 & 24 & -4 & 0.83 & $\begin{array}{c}\text { Less } \\
\text { Pharmacists }\end{array}$ \\
\hline
\end{tabular}

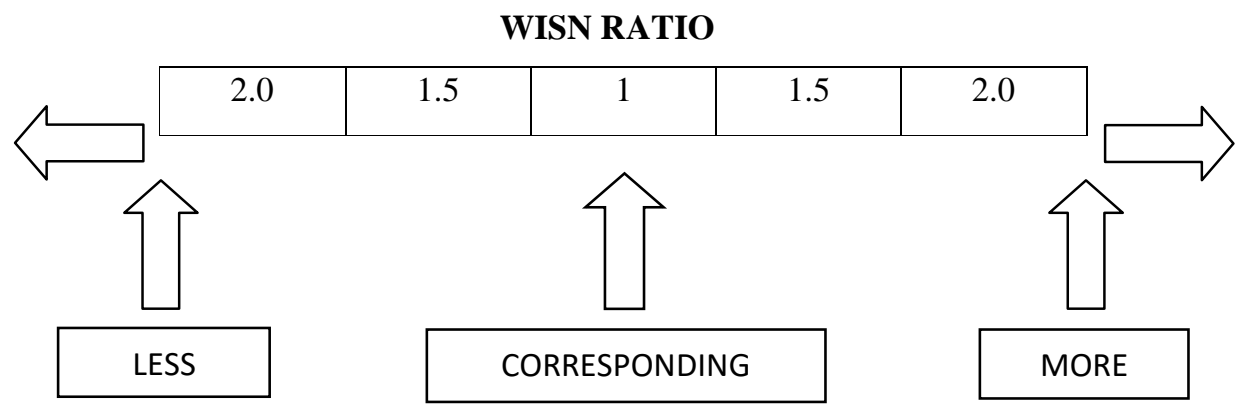

